KILIAN J. SAENGER, M.Sc. candidate ${ }^{1}$

E-mail: kilian.saenger@fh-erfurt.de

TIMO SIMON, M.Sc. ${ }^{2}$

E-mail: timo.simon@deutschebahn.com

FLORIAN HEINITZ, Prof.Dr. ${ }^{1}$

E-mail: heinitz@fh-erfurt.de

${ }^{1}$ Erfurt University of Applied Sciences

Altonaer Str. 25, 99085 Erfurt, Germany

2 DB Engineering \& Consulting $\mathrm{GmbH}$

Torgauer Str. 12-15, 10829 Berlin, Germany
Transport and Sustainable Development Original Scientific Paper Submitted: 30 June 2021 Accepted: 20 Oct. 2021

\title{
CAPABILITIES OF A PERIODIC CONTAINERISED RAILFREIGHT SYSTEM IN GERMANY
}

\begin{abstract}
Based on an analysis of the developments to date, this article originates from and then substantiates long-discussed approaches of a fast, periodic unaccompanied combined rail freight transport network for Germany that corresponds to the target modal split. A four-stage scenario of a market entry is developed. The presented solution incorporates potentially novel aspects such as a network design based on the Deutschlandtakt Cargo integrated periodic timetable framework, the prospective quantity structures as of 2030, and a segmentation for a route-specific mix of two major shipping container types. The set of assessment indicators derived by the model allows to gain insights on the achievable capacities and service levels versus the addressable freight transport demand as well as consequential cost/benefit functions.
\end{abstract}

\section{KEYWORDS}

rail freight transport; integrated periodic timetable; combined transport; freight transport demand modelling; periodic freight rail path; Germany.

\section{INTRODUCTION}

\subsection{Background}

The imperative climate protection regulation and the unabatedly ambitious objectives of a substantial modal shift from road to rail shall be brought in consistency with the technological viability and prospective market reactions of a supply-driven extended rail freight system. Discussions on how to increase freight traffic by rail have been going on for decades. The already saturated road corridors in Central Europe cannot cope with more growth unless the service levels decrease further and infrastructure will be even more severely affected by heavy trucks. The current decarbonisation debate is once again putting the spotlight on a much greater role for freight rail in managing rising transport volumes and lowering greenhouse gas emissions. However, this preconceived pathway is subject to demanding conditions as well. Comparative advantages in terms of energy consumption, external costs, and savings in driving personnel are obvious but not decisive aspects. In reality, due to the slow pace of infrastructure development, often in conflict with residents' interests, not even the resulting additional traffic can be adequately absorbed. Despite further increasing intramodal competition - with a medium term Herfindahl index below 0.25 - which has stimulated the German rail freight market, existing operating models fell short of expectations of a considerable modal shift towards rail.

As a result, the rail market share has remained at around 18 percent, with a slight upward trend over the past decade [1]. The freight volume projections for 2030 also do not assume that this situation will change significantly in the medium term. Taking a European comparison, Germany can be found in a midfield of the ranking [2]. Countries with a higher modal split either invest significantly more into railways or benefit from transport market demand dominated by commodities suited to being carried by the railways. For example, Austria and Switzerland belong to this first group. The second group includes Estonia and Latvia, which also exhibit the highest net tonne kilometres per train kilometres in Europe - due to the aforementioned rail affinity of most of the cargo [3].

A viable approach to improve the availability and raise service levels is containerised system transports, thus transferring some operating concepts of passenger traffic to freight traffic. This presupposes 
fast access to/from combined transport terminals and expedite direct transfers between trains within. Assuming this, the railways furthermore will need to provide a highly standardised regular interval service for full container loads upfront and market it similar to an airline's seat inventory afterwards. It still appears questionable whether this challenge can be managed both capacitively and logistically. Currently, just about five percent of trailers in Germany are cranable. Even if new operation infrastructure such as the 2021-opened Lehrte hub points precisely in this direction, most terminals do not meet the above requirements of combined transport [4].

\subsection{Research objectives}

On the understanding that combined transport needs to restore flexibility through dense integrated periodic ("clockface") timetables (ITF) in the extent of market requirements, the research was intended to investigate the conditions under which such transports could be implemented. The focus is on the resulting demand and supply side interaction.

The transport political goals were deliberately set quite high. Taking a targeted 25 percent market share at its word, the aim of the scenario and its underlying model to be created was to establish comprehensible system transport supply concepts with consistent quantity structures first. The speed-up, high availability, and considerably more volumes on offer over time should differentiate this service from the still-coexisting direct train and single wagon load transport. Based on it, the task was to check on which corridors system transports can best be realised and whether the capacities set in the German timetable are foreseeably sufficient to achieve such a modal split. This is organised in expansion stages. Sufficient expected demand is a necessary precondition to support a specific route. Since government subsidies certainly intervene in the tariffs, the ultimately decisive question of price competitiveness was left aside for the time being.

In the final analysis, the modelling work should provide the necessary indicators that allow for subsequent hypothesis tests and suggest an integrated periodic timetable at an optimal system size, taking aggregated microeconomic and social benefits versus expected incremental costs on top of the existing road and railway supply into account. While the benefits are assumed to be degressive, the average cost curve is likely to be U-shaped (Figure 1).

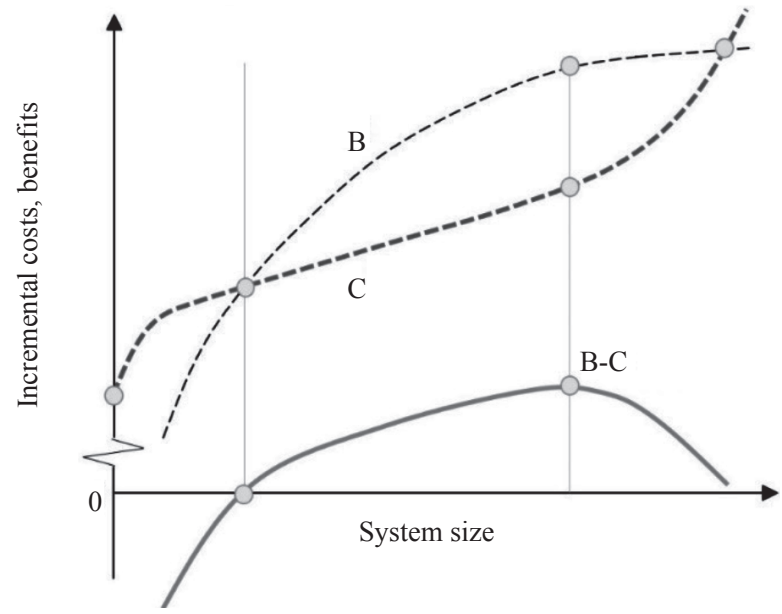

Figure 1 - Costs function (C) versus Benefit (B) curves depending on the system size

Expected outcomes could substantiate the definition of appropriate horizons of infrastructure requirements of a stepwise network extension, until the marginal net utility falls below the zero point.

\subsection{Previous work}

Although it can be assumed that national and transnational railroad companies have conducted their own research on the subject, the literature review is based only on non-proprietary documents. Expedite containerised rail freight, with emphasis on seaport-hinterland relations, has been widely addressed by conceptual and applied research worldwide. This includes aspects such as

- demonstration of proven strategies to encourage rail freight transportation $[5,6]$

- management of port container transshipment in conjunction with freight rail timetable construction $[7,8]$

- operational efficiency of rail freight in providing hinterland market access [9]

- opportunities of high-speed rail freight [10]

- improvement of cross-border procedures, complicated by gauge change [11], and

- construction of efficient periodic train paths in the case of mixed traffic allocation and its impact on both inter and intra-modal competition. [12, 13].

For the literature underlying the subsequently studied case of Germany, we refer to section 2.

\section{METHODOLOGY}

The research presented picks up on the rich literature of prior insights on success factors and impediments of fast combined transport. Before describing 
the multistep network design process deployed in section 2.3, the situation to date and attempts at improvement will be reflected in 2.1 and 2.2 respectively. A literature-based review of technical-organisational approaches and proposals of the past is provided. To ease the accessibility of the remaining article, a list of abbreviations used in the following can be found in Table 1 .

Table 1 - List of abbreviations

\begin{tabular}{||l||l||}
\hline BVWP & $\begin{array}{l}\text { Federal Transport Infrastructure Planning } \\
\text { Framework of Germany }\end{array}$ \\
\hline CT & Combined Transport \\
\hline DB & Deutsche Bahn / German Railways \\
\hline EU & European Union \\
\hline ITF & $\begin{array}{l}\text { Integrated Periodic Timetable / Clockface time- } \\
\text { tabling }\end{array}$ \\
\hline NUTS & Nomenclature of Territorial Units for Statistics \\
\hline O-D & Origin-Destination (Pair/Relation) \\
\hline PFRP & Periodic Freight Rail Path \\
\hline SWL & Single Wagon Load \\
\hline TEU & Twenty-Foot Equivalent (Unit of Measurement) \\
\hline \hline
\end{tabular}

\subsection{Review of initial conditions}

With more than 3.5 billion tonnes of goods conveyed on the roads of its territory, Germany features the most important surface transport market on the continent [14]. The country is also crossed by six of the eleven European multimodal (rail) freight corridors [15]. Mixed traffic of significant speed differentials can still be found on these corridor routes to this day, thus delimiting capacity [16]. The upgrading of these routes is preferentially supported by EU funds in order to create a seamless European network for freight transport according to the most uniform technical standards possible. In particular, the aim is to eliminate bottlenecks [17], set to avoid problems in the railway supply chains [18]. Traditionally, particular importance of transport policies is attached to multimodal transport [19]. In order to be capacitively capable of handling considerably more cargo, path conflicts between passenger and freight traffic on the rail network are apparent and subject to regulation processes by the infrastructure provider [20]. Especially high traffic corridors often involve longer idle times for freight trains. Passenger traffic is given priority, especially in suburban regional rail transport networks [21], thus imposing major restrictions on freight rail companies [22], leading to higher production costs for railway undertakings in terms of personnel and energy (due to accelerating from frequent stops) and non-competitive service levels [23]. Eighty percent of all train paths are allocated as systematised periodic train paths with the timetable. Moreover, the lengthy train path application process shrinks the logistical flexibility [24], although increasingly being demanded by potential rail freight customers (cf. [19] p.68).

Combined transport is distinguished from other multimodal transports by the transshipment of goods without changing the transport vessel (cf. [18] p.40), forming sub-mode in addition to direct block trains and single-wagon transport [25]. At the price of additional transshipment effort, the strengths of the individual modes of transport for each section can be optimally used on their respective legs (cf. [18] p.41). However, the limited terminal quality and transshipment performance is a decisive barrier [26]. In terms of intermodal terminals, there is already a dense network in Germany. Combined transport currently features 177 terminals, with another 11 facilities to enter revenue operation [27]. The aforementioned Lehrte hub is exemplary for that new generation (cf. [25], p.487). However, the vast majority of terminals are not suitable for fast through traffic and efficient train-to-train transshipments. Due to this, only a fraction of the demand potential and network economies can be leveraged. In consequence, many system transports in combined transport are up to now only carried out as point-to-point service at low frequencies.

\subsection{Synthesis of previous improvement approaches}

Numerous theoretical proposals and practical attempts to improve combined transport's attractiveness, to overcome outdated technologies, and to increase train path capacities and door-to-door levels of service could be recorded. Frequently, regularly scheduled transports are already used in combined transport, which at least partially fulfil the criteria of system traffic. In the process, trains were offered between major conurbations at night, particularly on routes within Germany or to neighbouring countries [28]. A clear product differentiation to SWL traffic of total transport times of up to three days can be achieved [29], although frequencies of the direct trains are still lagging behind usual frequencies in 
passenger rail networks. Focusing on Germany only, several notable implementations were identified:

- The Inter Cargo Express was a service introduced in 1984. Each train had a capacity of 900 tonnes and could reach speeds beyond $120 \mathrm{~km} / \mathrm{h}$ (cf. [28]). Stepwise, the 17 largest economic centres in West Germany were connected [30]. For example, a journey from Hamburg to $\mathrm{Mu}-$ nich took only 8.5 hours (cf. [30]), guaranteeing a punctuality rate of $94 \%$ [31]. The concept proved to be unprofitable due to the unrealistic cost levels and a marketing worth improving. It was finally discontinued in 1995. Similar to this, the cooperation partners Deutsche Bahn and the Deutsche Post DHL ran the Parcel InterCity.

- The complexity of container routing requires advanced digitalisation. Kombiverkehr as an innovative logistics service provider developed and markets a Europe-wide portal where connections and free capacities can be easily queried online [32]. However, direct online booking is not possible; instead, there is an electronic inquiry form linked. This is nevertheless an important step for digitisation of sales in the railway sector.

- The Deutschlandtakt is a concept for an integral periodic timetable that is intended to bring more freight onto the railways in addition to passenger traffic. The core idea is to expand the infrastructure in a targeted manner on the basis of a target timetable to be expanded [33], thus allowing system transports to be planned more efficiently and dependably. In particular, improved connections and the systematic consideration of freight traffic should ensure shorter travel and transport times [34]. Regardless of the known shortcomings such as the sensitivity to onward delays after the handover of trains on borders and the subordination of the interests of a vivid intramodal competition to an efficient overall system condition, the aim is to implement the concept step by step within the next decades (cf. [20]).

- Smart cargo stations are a favoured approach of solving the problem of slow reloading in terminals. Turning the loading tracks from sidings into main tracks and offering new types of terminals are key to minimise the stopping times of container trains. [35] In addition to this, new and more economic solutions such as Innovatrain's ContainerMover device facilitate transshipments $[36,37]$.
In conclusion, the elements of a technical solution given to implement a synthesis of Kortschak's CARGONET vision [38] and of Busche \& Weigand [39] will form the basis for further consideration. The following, slightly modified, guiding principles are adopted as model assumptions. These include:

- cross-border block trains with the length of 700 meters (excl. 40 meters buffer for optional carriages)

- state-of-the-art multi-system locomotives and flexible carrying wagons to accommodate containers (in the following used as a generic term for standardised containers, semitrailers, and swap bodies)

- fast unloading and uploading of containers (15 to 30 minutes for the entire train)

- neither shunting nor coupling of wagons

- dependable, highest priority run in the network

- periodic timetabling, allowing for $100-120 \mathrm{~km} / \mathrm{h}$ non-stop between terminals

- simultaneous train path planning with passenger trains within the Deutschlandtakt Cargo

- optimisation of previously undeveloped bottlenecks in favour of combined transport

- optional line swap to cover further transshipment-free O-D relations

- up to 16; lines gradual start-up of first lines with horizontal handling systems.

\subsection{Network design and assessment model outline}

The system transport network to be established should offer the by-products of continental and seaport hinterland containerised traffic of expedite, but not necessarily ultimately time critical cargo - thus covering a rather broad range of willingness-to-pay, yet without explicit reference to the pricing. It is noteworthy that shipments requiring special handling such as cooling or accompanying (e.g. case of hazardous goods) are exempted here.

In practice, each system transport route needs a planning and implementation lead time of at least five years. To limit market entry risks, a stepwise implementation by stages of expansion, bundling lines by descending net benefit, is suggested. Figure 2 overviews the workflow used to derive the indicators of relevance for the planning process.

The overall procedure draws on elements of the four-step-algorithm of transport modelling in time-expanded multimodal networks, combined with timetabling and assessment mechanisms. For 


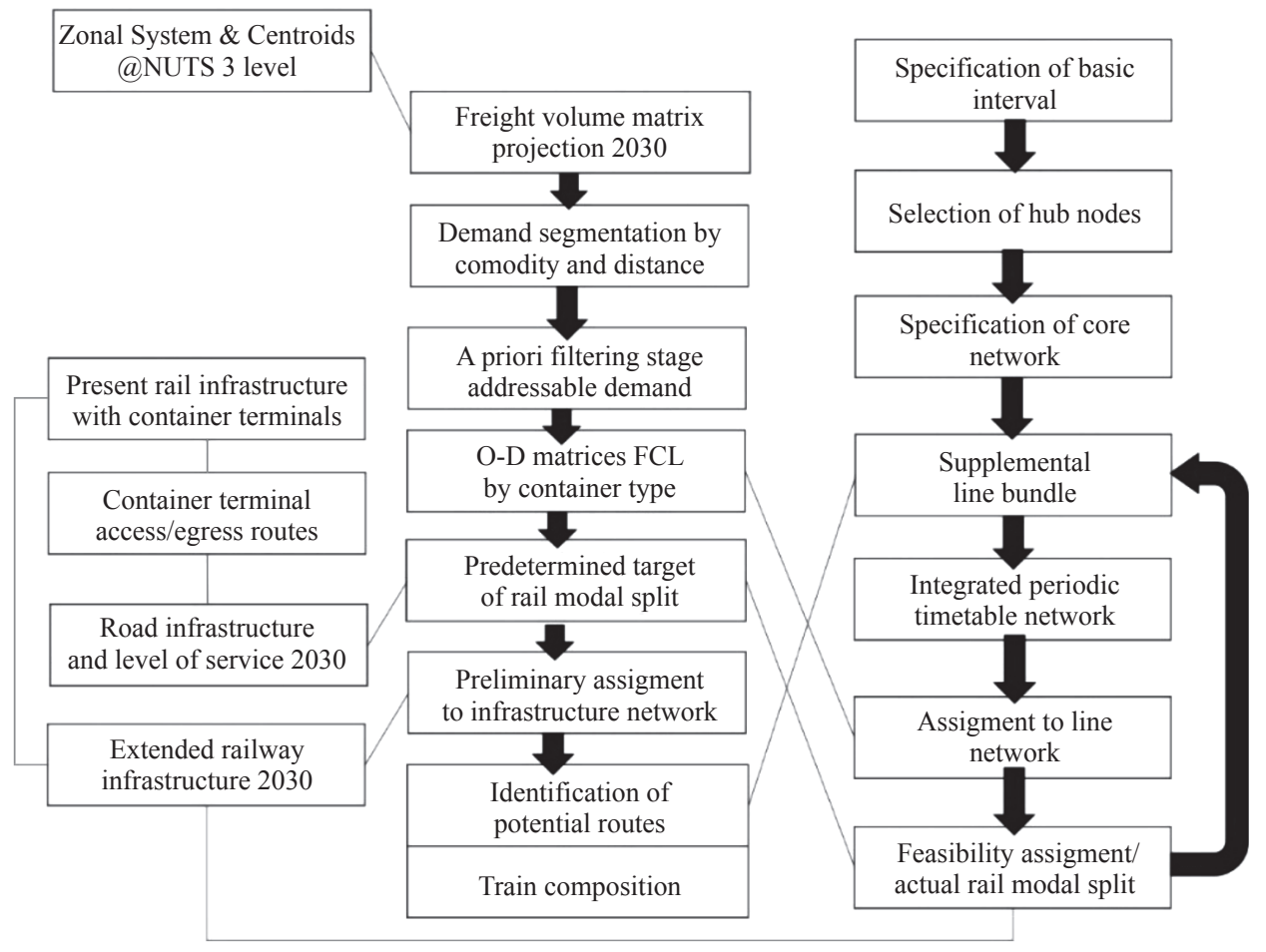

Figure 2-Model workflow overview

example, the demand matrix assignment to the periodic line network presupposes an implicit route split for all combinations of relevant departure/arrival terminal.

Freight volume matrices 2030 of the BVWP national infrastructure planning framework on NUTS3 level were used. The top origin-destination pairs which could support direct trains were identified. The segmentation of the relevant market was conducted by differentiating market shares by commodity group as well as a commodity and distance-specific fuzzy filtering, using a linear transition function in the interval between 250 to 350 kilometres of the main-run distance. An upper bound of rail affinity was estimated for each freight commodity group. Moreover, relevant sections on trans-European traffic were assigned to/from 14 railway border crossings.

The analysis of demand potential concluded that approximately $28 \%$ of the 837 billion tonne-kilometres per year in German freight demand are suitable for rail. In total, this would be equivalent to an increase of about ten percentage points compared to the status quo.

The tonnage matrices were transferred into matrices of the respective TEU loading units. O-D pair involving seaports were identified. For simplification, it was assumed that $40 \mathrm{ft}$ containers continue to dominate the seaport-hinterland relations, whereas Euro pallet size compatible $45 \mathrm{ft}$ containers will become the most used unit size at continental relations. Furthermore, there is the assumption of an 80 percent utilisation with regard to maximum container payload on average.

The travel time matrix of the BVWP base case road network [40], modified by adding statutory driver rest periods according to regulation EC $561 / 2006$, was used as a reference level of service. (Notably, the truck drivers' hours-of-service regulation is not only a crucial driver for the safety of continental road transport, but at the same time an indirect support for the competitiveness of freight rail.)

\section{RESULTS}

In the following section, the quantity structures of the resulting network model (3.1) and obtained assessment indicators (3.2) are presented.

\subsection{Network model and quantity structure}

\section{Zonal system and network access}

The zonal system on NUTS 3 level comprises 402 cells, of which 14 are railway border crossings. The 177 existing terminals as of 2020 (Figure 3), supplemented by another four high-performance terminals 


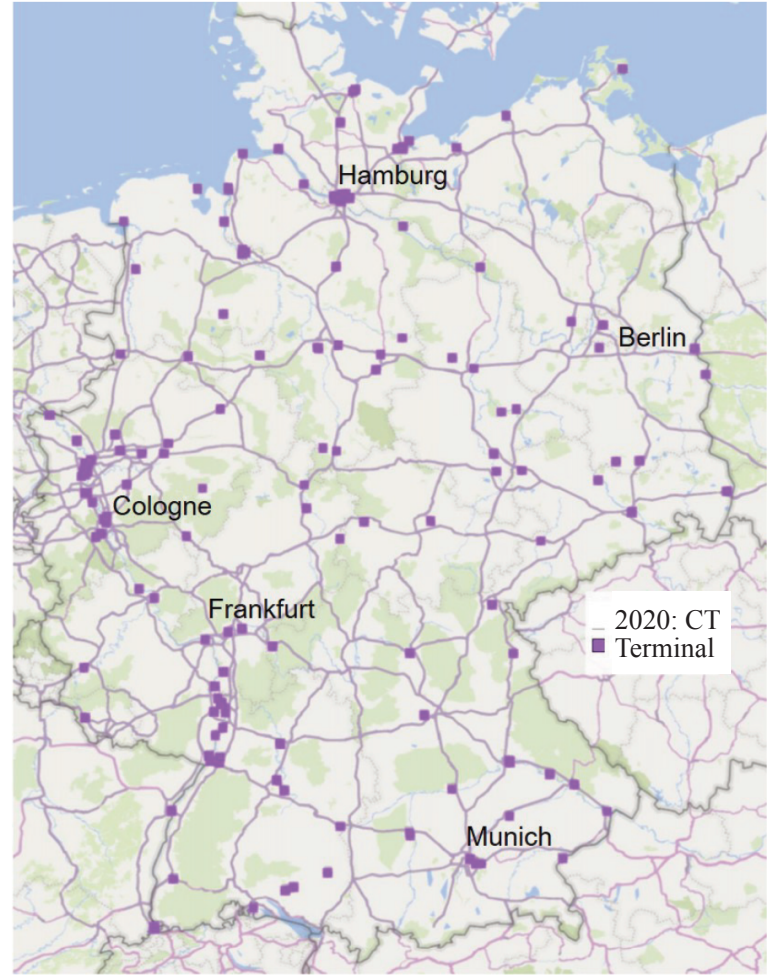

Figure 3 - CT Terminals as of 2020

based on the Lehrte example at Hamm/Westfalen, Eichenberg, Darmstadt, and Wustermark. For each cell, between three and four access and egress connector links to the nearest facilities were created, resulting in 2,538 connector links which are assumed to be served with just-in-time delivery.

\section{Demand potential}

The origin-destination matrices comprise an annual demand of 2.7 million $40 \mathrm{ft}$ containers and 12.0 million $45 \mathrm{ft}$ containers to be shipped. Based on the road network distances, this volume would correspond to an annual transport of 125 billion tonne-kilometres or $15 \%$ of the 2030 projections' totals.

\section{Railway network model}

The underlying physical railway network has a high level of detail. The eligible sub-network for rail cargo was used for a preliminary assignment of the matrices, assuming a $20 \mathrm{ft}$-equivalent and unlimited train path allocation (Figure 4).

Based on this, a simplified infrastructure model was derived, avoiding the already overloaded corridors of intercity passenger rail on the one hand and presupposing electrified double-track lines of at least $120 \mathrm{~km} / \mathrm{h}$ maximum speed as links on the other (Figure 5). Based on this, a spatiotemporal trunk network between the hub nodes has been fixed

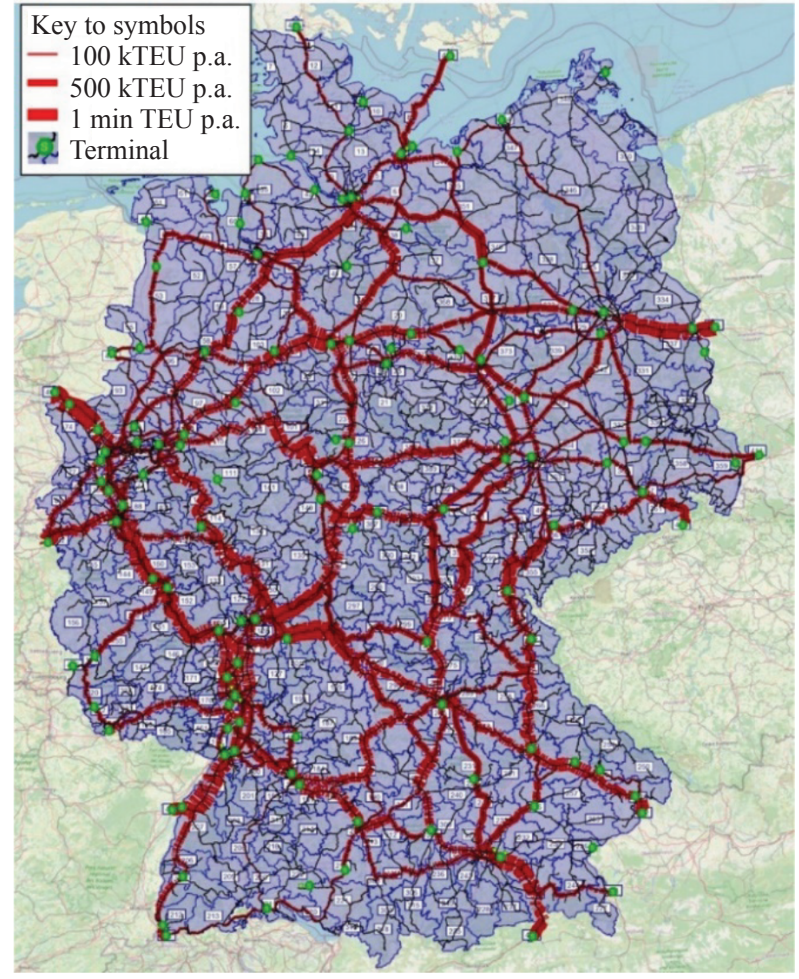

Figure 4 - Preliminary assignment result

as a framework (Figure 6). The hub operations were specifically scheduled so that no overload occurs even with several potential intermediate stops, that is, remains within the production possibilities.

\section{Rolling stock and feeder fleets}

The maximum usable train length less the traction unit (Vectron or similar) is assumed to be 680 meters. The combination of seaport-hinterland and

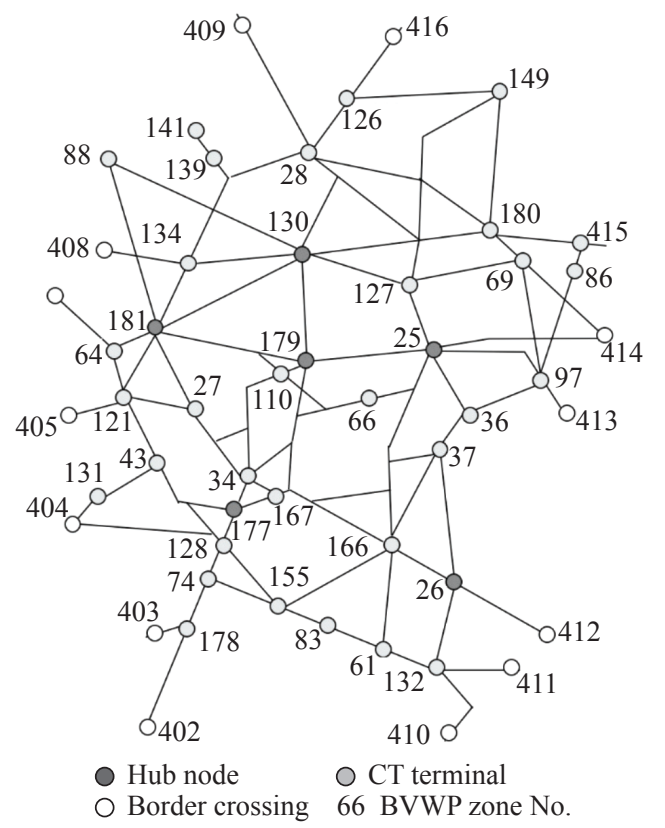

Figure 5 - Resulting freight rail infrastructure model 


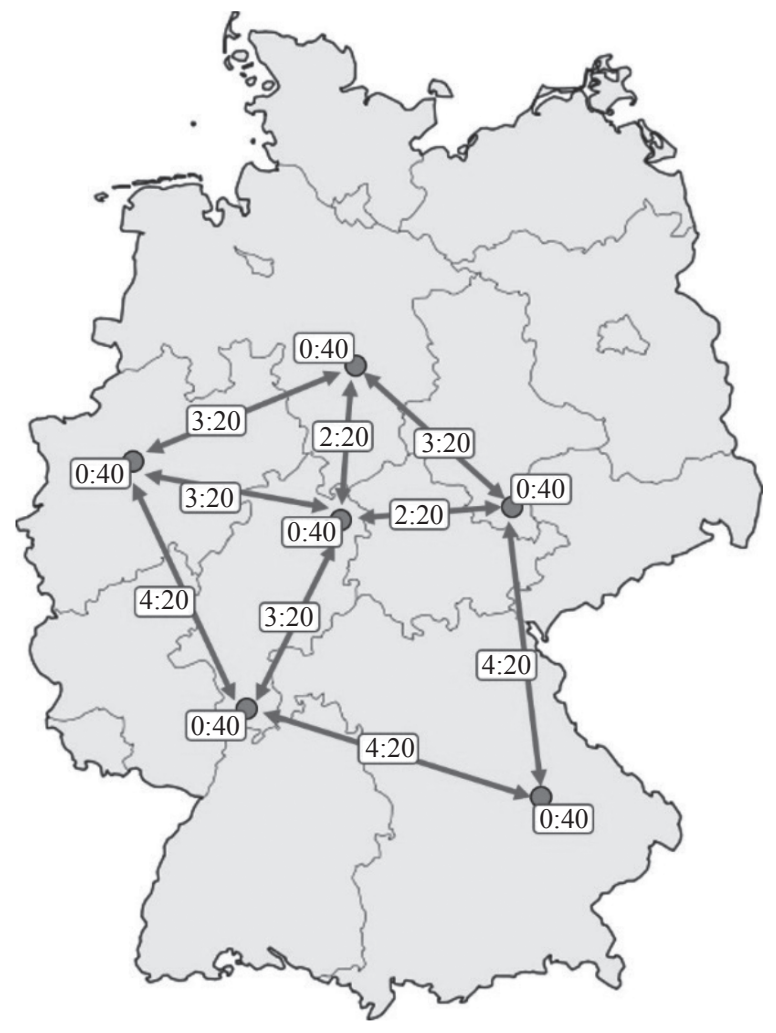

Figure 6-Trunk network of six hub nodes

continental traffic poses a challenge for the selections of rolling stock, mainly because of the different container sizes and payloads.

Different types of carrying wagons were analysed. The optimum wagon currently available for seaport hinterland traffic, characterised by the transport of relatively light $40 \mathrm{ft}$ containers, is the four-axle $80 \mathrm{ft} \mathrm{Sggns.} \mathrm{Its} \mathrm{tare} \mathrm{weight} \mathrm{is} \mathrm{about} 22$ tonnes. The maximum number of wagons would be 26 , i.e., 52 40ft container positions or 104 TEU. However, due to the loading length of $80 \mathrm{ft}$, only one $45 \mathrm{ft}$ container could be accommodated per wagon - instead of two $40 \mathrm{ft}$ containers, as shown in Figure $7 a$.

For continental traffic, type Sggmrss (tare 29 tonnes) with Jacob's bogies would be suitable as a reference wagon, since the pallet-wide $45 \mathrm{ft}$ containers are becoming increasingly common (Figure $7 b$ ). This articulated container wagon is based on two $45 \mathrm{ft}$ platforms and three bogies. Containers and swap bodies of various lengths $(20 \mathrm{ft}, 30 \mathrm{ft}, 40 \mathrm{ft}$, and $45 \mathrm{ft}$ ) can be placed on these [41]. The wagon train would then have a maximum of 23 wagons, i.e., 46 bays. Due to the two additional axles compared to the Sggns, this wagon is characterised by its high loading weight.

In comparison of their degrees of capacity utilisation and in the light of the demand structure, the train sets are assumed to be predominantly formed from six-axle Sggmrss, complemented by Sggns depending on the share of seaport-hinterland traffic.

Pre-run and post-run blocks are under the assumption of a continuous vehicle rotation, allowing for at least three daily cycles with a number of (conventional) trucks dimensioned according to the flow of goods. One vehicle per $40 \mathrm{ft} / 45 \mathrm{ft}$ unit (or two $20 \mathrm{ft}$ ) is deployed.

\section{Line network and timetabling}

The Deutschlandtakt Cargo ITF framework was taken as a basis to identify train on paths on highly frequented corridors which will be generally viable in the long run (Figure 8).

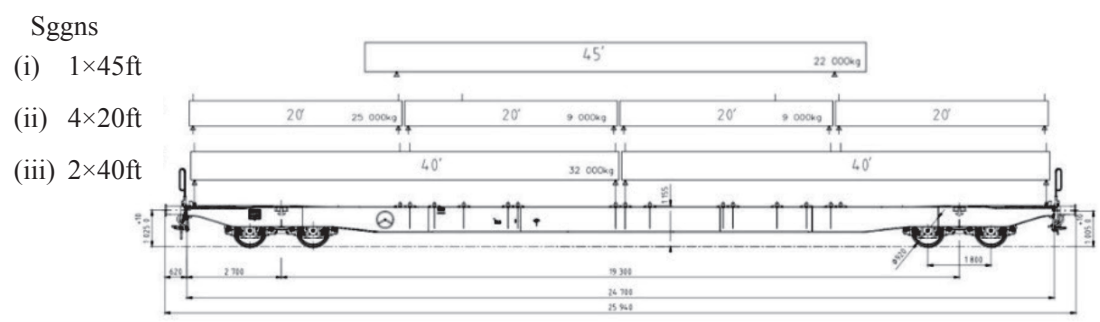

a)

Sggns

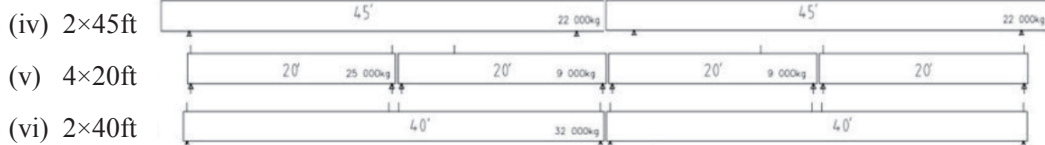

(vi) $2 \times 40 \mathrm{ft}$

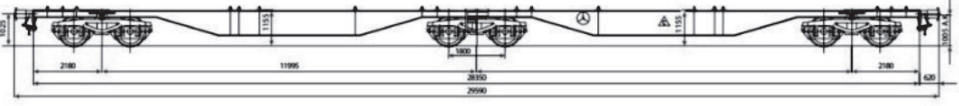

b)

Figure 7 - Carrying wagon types and container loading options considered [42,43] 
The proposed line concepts for a detailed investigation corresponding to the stages one to four are depicted in Figure 9. The production system distinguishes between the selected ITF hub nodes and other terminals served. The envisaged lines of either 60 or 120 minutes headway are highlighted in different colour. Routing of lines via the most operationally suitable terminals was done independently of the question of their operators and by a preliminary train path allocation to the physical graph of rail infrastructure.

Since the maximum headway is 120 minutes, the route search was performed and its results were weighted equally for both even and uneven hours of departure. At hubs and selected other terminals, transshipments were allowed if there was at least 20 minutes of overlapping train stopping time.

\subsection{Assessment Indicators}

The basic supply and demand data of the model instances for the specified four stages of extension and the respective assessment results from network assignment are given in Table 2.
The selected indicators, representing the vehicular transport performance, the addressable demand and the service levels, can be combined in indexed scatter plots. Corresponding exemplary trajectories from the first to the fourth stage of extension can be derived (Figure 10).

\section{DISCUSSION}

With some resemblance to the creation of the German passenger intercity network in the past - spanning more than a decade - a hypothetical network of an extended containerised system of transport was investigated by defining four gradual stages of extension according to possible planning horizons in the late 2020. Although terminal logistics is omitted here, a sufficient level of detail has been reached. There are several meaningful results:

The main finding of the calculations is that such periodic operations of high frequency would be eminently capable of handling the envisaged containerised segment of the forecasted freight vol-

Table 2 - Modelling results

\begin{tabular}{|c|c|c|c|c|}
\hline Indicator & Stage 1 & Stage 2 & Stage 3 & Stage 4 \\
\hline Number of bi-directional lines operated & 4 & 8 & 11 & 14 \\
\hline Number domestic terminals served (of which ITF hubs) & $14(5)$ & $24(7)$ & $24(7)$ & $40(7)$ \\
\hline Line network size $(1,000 \mathrm{~km})$ & 6.8 & 13.0 & 18.2 & 24.0 \\
\hline Average line length & 850 & 813 & 827 & 857 \\
\hline Minimum of train sets required (hourly service 24/7) & 101 & 188 & 262 & 344 \\
\hline $\begin{array}{l}\text { Total train performance [mn vehkm p.a.] (hourly service } 360 \\
\text { days) }\end{array}$ & 59 & 112 & 157 & 207 \\
\hline Average annual mileage train set $(1000 \mathrm{~km})$ & 584 & 596 & 600 & 602 \\
\hline $\begin{array}{l}\text { Container bays } 40 \mathrm{ft} / 45 \mathrm{ft} \\
\text { offered p.a. }[1,000] \text { at } 1.4 \text { per run } \\
\text { (percent of demand potential) }\end{array}$ & $\begin{array}{l}2,371 \\
(16.1)\end{array}$ & $\begin{array}{c}4,742 \\
(32)\end{array}$ & $\begin{array}{c}6,520 \\
(44)\end{array}$ & $\begin{array}{c}8,298 \\
(56)\end{array}$ \\
\hline Share of O-D pairs served (\%) & 4.2 & 17.6 & 17.6 & 24.8 \\
\hline Unweighted deviation factor combined transport vs. road (\%) & 53 & 48 & 38 & 34 \\
\hline Unweighted transport time ratio combined T./Road (\%) & 234 & 208 & 194 & 173 \\
\hline Share of served O-D pairs requiring transshipments en route (\%) & 72 & 61 & 48 & 38 \\
\hline $\begin{array}{l}\text { Total units assigned p.a. }[1,000] \\
\text { (percent of demand potential) }\end{array}$ & $\begin{array}{l}876 \\
(5.9)\end{array}$ & $\begin{array}{l}1.822 \\
(12.4)\end{array}$ & $\begin{array}{l}3.494 \\
(23.9)\end{array}$ & $\begin{array}{l}5.843 \\
(39.7)\end{array}$ \\
\hline Rail transport performance at full utilisation, gross [bn tkm] & 72.3 & 137.2 & 192.3 & 253.8 \\
\hline Domestic pre-/post-run vehicles deployed & 104 & 373 & 862 & 1,443 \\
\hline Domestic pre- and post-run road transport performance $[\mathrm{mn} \mathrm{tkm}]$ & 337 & 683 & 1,290 & 2,359 \\
\hline
\end{tabular}




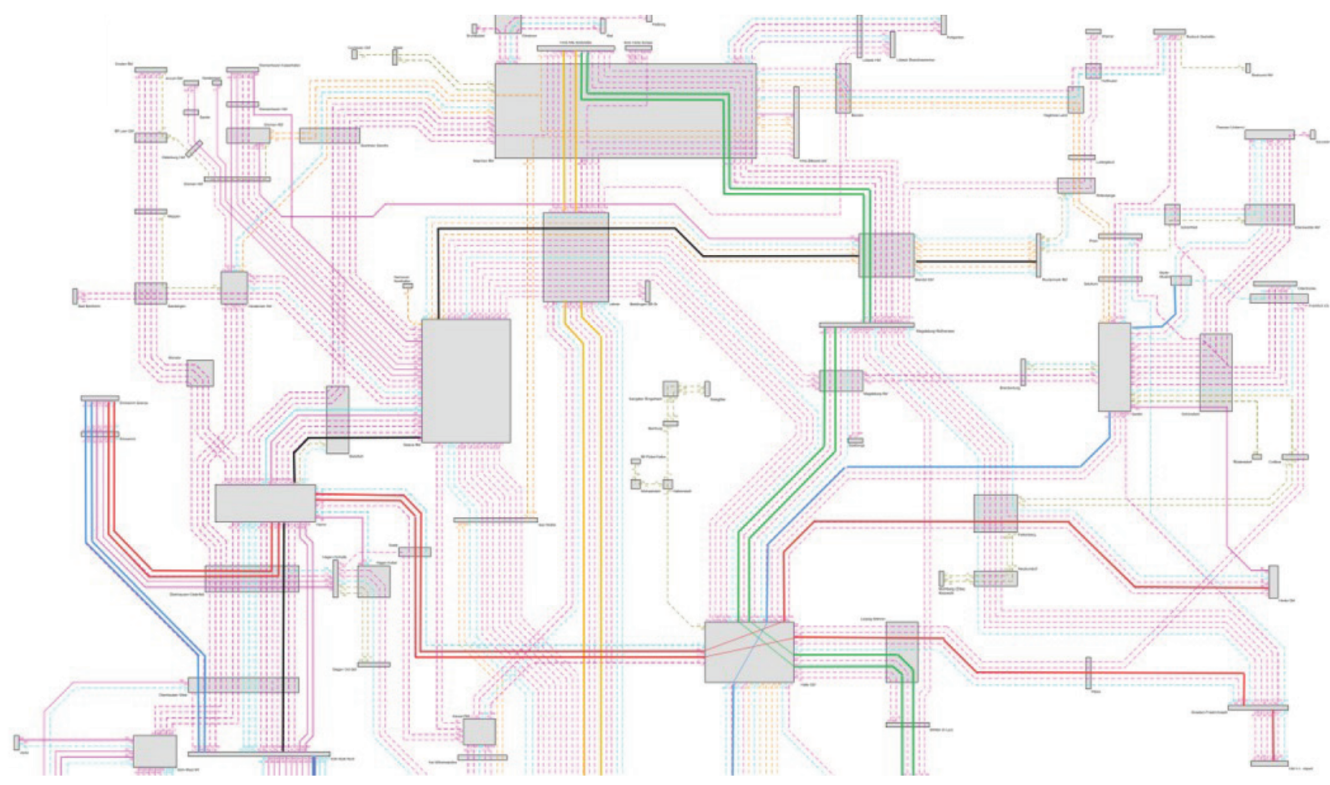

Figure 8 - Train paths in accordance with the Deutschlandtakt Master Timetable [8]
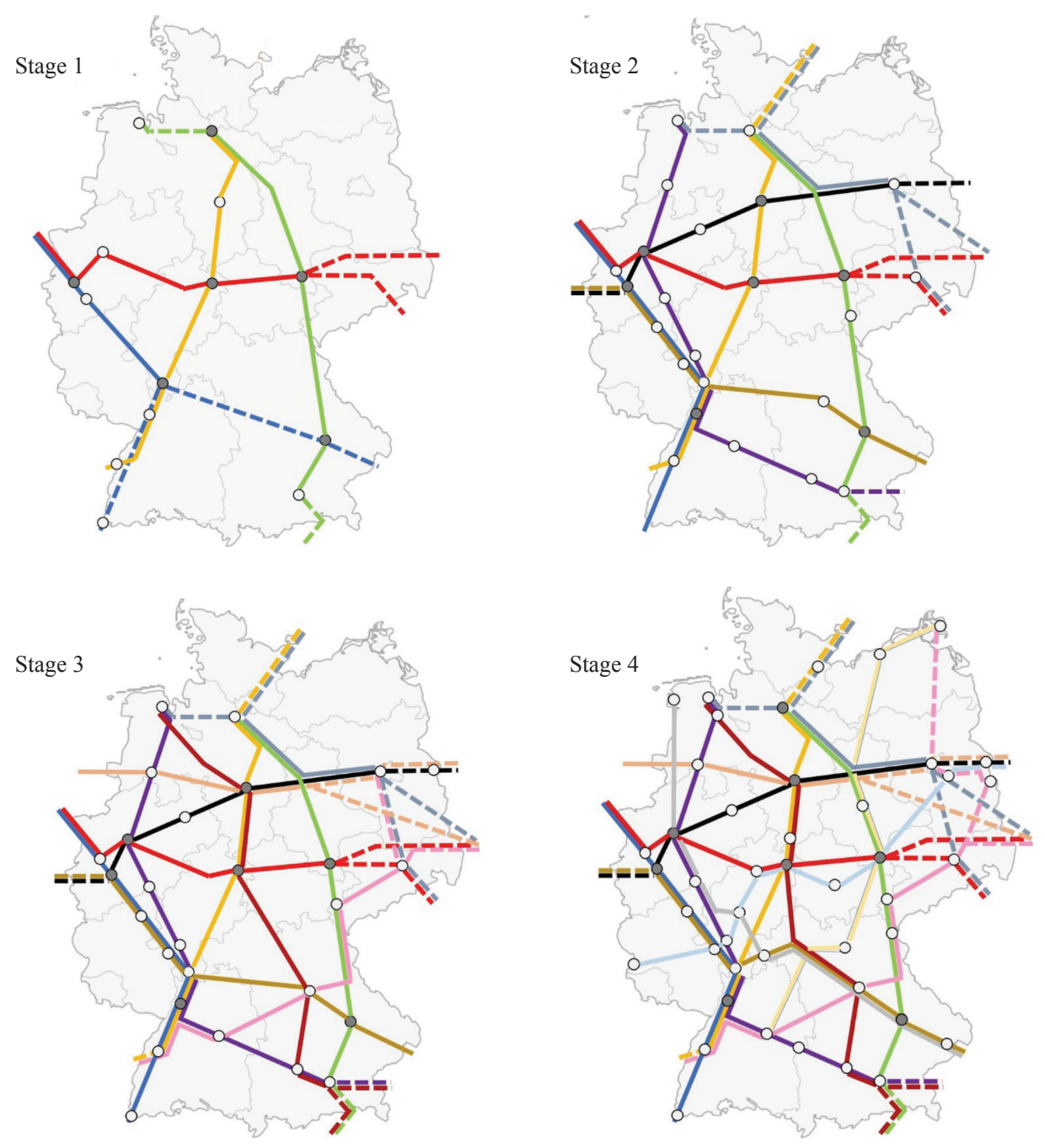

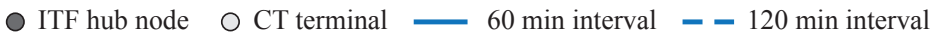

Figure 9-ITF line concepts at stages of extension 1 to 4 

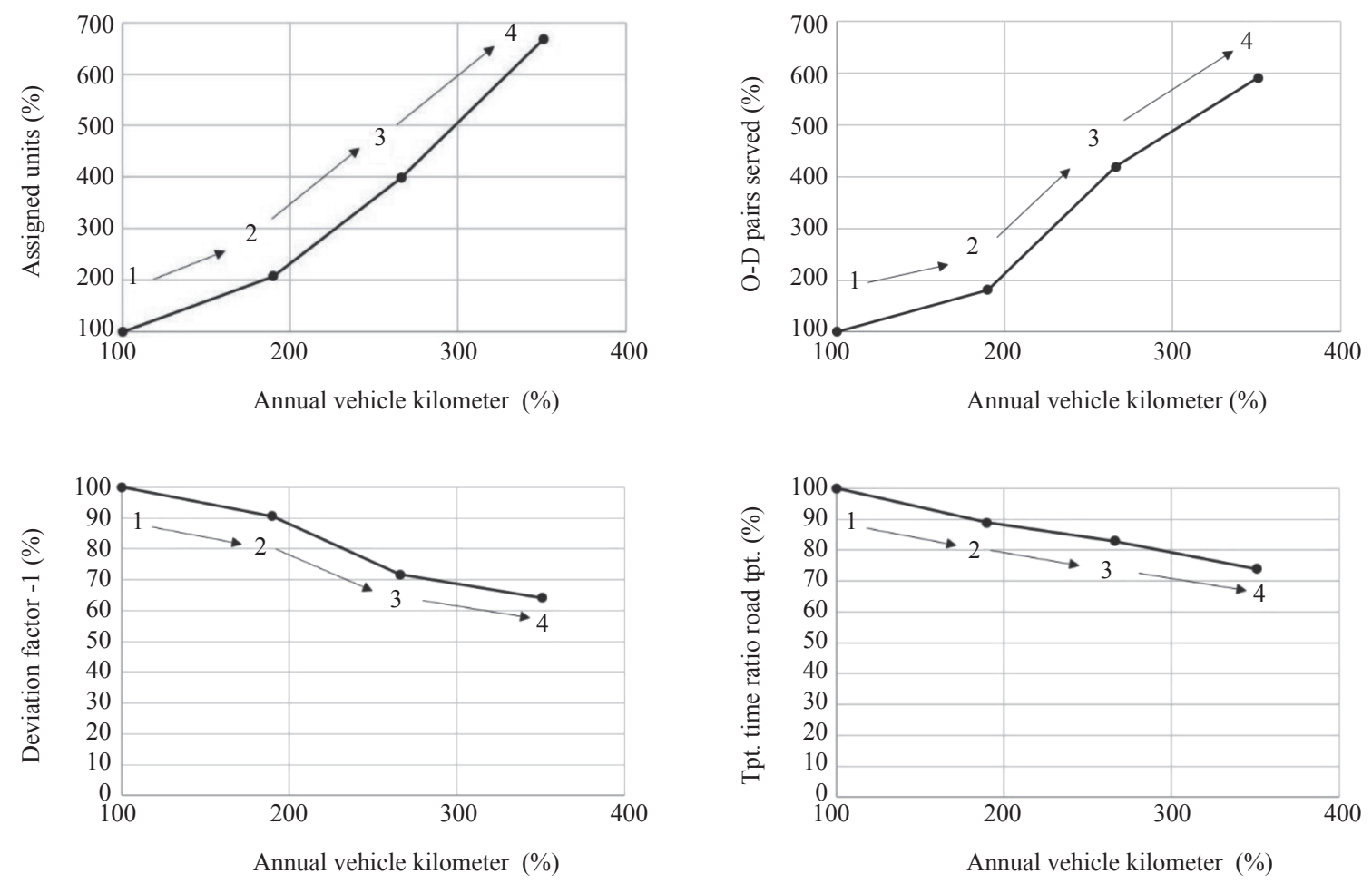

Figure 10 - Cost-effectiveness and competitiveness assessment at stages of extension 1 to 4

ume. The contribution of combined transport to the BVWP reference scenario of $2030,8 \%$ of the $18.5 \%$ of total rail market share could be nearly doubled.

Regardless of the actual acceptance on the demand side, the trajectories between the stages of extension provide indications of the presumed cost and benefit curves. The material and logistic effort of more competitiveness to road transport is considerable.

Although decisive propositions about market opportunities and thus actual modal shift potential cannot be accurately derived at this point, their preconditions in terms of comparative levels of service to road transport, particularly detour factors (distance as a proxy indicator of operating cost), the relative total transport times, and the share origin-destination pairs with direct or one-stop connections can be verifiably improved in extending the combined transport's line network.

In examining the assessment indicators' progress from stage to stage, a modal share of $25 \%$ of transport performance cannot be reached without excessively enlarging the terminal catchments. The dilemma situation of the limited market coverage can be studied: much wider terminal catchments imply lower level of service relative to road transport and an increase of detour factor due to increasing share of actually unproductive route segments. Connectivity comes at the expense of straight-line speed.

In addition to the bottlenecks in the infrastructure and at the terminals already mentioned, further difficulties are to be expected in the case of the increase in the modal split of rail by approximately 10 percentage points assumed in this study. This applies, among other things, to the chronic shortage of train driving staff. The apparently too low attractiveness of the profession would have to be improved by appropriate measures.

It should also be noted that there will continue to be a shortage of slots in the targeted mixed-use operation on upgraded infrastructure. Potential goal conflicts with regard to passenger train paths and congestions, delay due to renewal of the networks, and maintenance of the network complicate the situation in the forthcoming years. This will make it particularly difficult to keep the impact low in the event of disruptions. Sophisticated, detailed incident concepts must be developed to minimise the impact. This is the only way to retain the rail companies' customers in the long term.

Nonetheless, depending on the stage of extension, up to $40 \%$ of the potential demand can be accommodated in the model. On the one hand, this is 
less than expected and could prove to be with regard to escalating expenditures for a full area coverage. On the other hand, this is not surprising since the guiding principle was to focus on the most viable corridors. Moreover, there should be enough remaining capacity to balance out demand fluctuations which would have to be flattened otherwise by means of yield management, thus creating severe logistical constraints.

Compared to SWL operations, there is a clear gain in service quality; however, it comes at a high price. Based on the current average full unit cost level of DB Cargo, the estimated total annual costs of such a system would amount to $€ 3$.8bn (stage 1) and $€ 13.4 \mathrm{bn}$ (stage 4). The considerable cost level is a conservative estimate. It would be offset by realised time cost savings on the one hand and net transport ecology effects on the other:

- Given a mean value of time of $€ 737$ per tonne and hour [44] and effective speedup would equal $€ 221.9 \mathrm{mn}$ each hour without taking further surpluses of induced traffic into account.

- Based on the specific emissions and traction energy mix so far, 9.75 million tonnes of $\mathrm{CO}_{2}$ could be saved on an annual basis at stage 4. Applying the widely used unit cost differentials of Germany yields to a total reduction of external costs of $€ 3.1$ bn p.a. at extension stage 4 [45].

\section{CONCLUSIONS}

Germany's location in the heart of Europe means that, in addition to considerable domestic traffic, it also has to accommodate significant growing cross-border traffic. To cope with it in the light of the challenges described at the beginning, the implementation of a more performant rail freight transport becomes acutely relevant [46]. Yet despite the obvious advantages of rail transport, a ubiquitous, substantial rise in freight train speed levels is still a vision. However, this does not apply to the choice of more efficient operating concepts.

The implementation of expedite system transports is considered a key supply-side measure in order to achieve ambitious modal shift targets. The call for integrated approaches towards an attractive choice option alternative to conventional road transport (cf. [22]) is without question.

Planning of market-mediated services relies on consistent quantity structures of the underlying supply-demand interaction. For this purpose, it is important and possible to support the consideration of investments and concrete service planning by means of transport modelling operated in analogy to passenger transport.

After more than two decades of advanced but largely "product undifferentiated liberalisation" [47] without an overarching, efficiency-oriented timetabling, more than a focus on direct trains should be possible in the context of system change in European rail freight.

In addressing this subject by a back-cast from a quantity structure equivalent to the target modal split, a freight transport model for Germany was built on the current state of information to estimate the market reach of a network of periodic lines and rather moderate technical requirements. Even though it was more difficult to accomplish, only non-proprietary, referenced sources were included in the process to assure reproducibility.

Potentially novel aspects are the timeline network design based on the Deutschlandtakt Cargo framework, the expected quantity structures as of 2030, and a segmentation for a route-specific mix of two major shipping container types. The distinction of four incremental stages of extension offers a roadmap to stepwise implementation.

There is still a number of limitations of the presented approach which can be taken as a recommendation for further research: (i) The price-competitiveness without subsidisation is questionable, also with several process chain elements not being specified. For example, the time to pre-build loading units was not included neither for road nor rail thus far. (ii) A cross-operator calibration based on actual values instead of only on forecast values would enable the transfer to concrete planning. (iii) The estimation of the terminals' transshipment performance, operating and external costs - including pre-/postrun road-based legs - needs to be refined, departing from average values. The informative value of the utilisation analysis should be improved by including a stochastic demand. (iv) The deployment of new transport and transshipment technologies about to be launched on the market shall be incorporated. (v) A transfer of the methodology to other, particularly neighbouring EU member states would be desirable.

The following policy recommendations can be given:

In contrast to the worthwhile (and often-requested) acceleration to $160 \mathrm{~km} / \mathrm{h}$ that would, among other things, imply a complete adoption 
of automatic centre buffer couplers, the presented concept remains within 'realistic bounds' for the horizon of $2030+/$ - three years. Towards achieving a competitive intermodal rail service, the recommended focus of investments should first be on:

- the increase of the share of cranable semi-trailers, possibly by prescribing standards and/or a non-distorting incentivisation

- the creation of fast access routes for through traffic from mainlines to the terminals involved, and the terminal's ability to meet the specification requirements set of a Smart Cargo Station, and

- a global multi-modal reservation and routing system for the container bay inventory that may already include price incentivisation to balance utilisation in case of scarcities.

In order to bundle demand for shorter periods, it would also be worth considering to integrate today's single wagon traffic into the hourly or two-hourly system connections. Together with classical combined transport, this might enable thin city pairs to be operated at a regular frequency and at a better cost level. Especially seaports are suitable as a start or end point for lines in system traffic due to the quantities loaded there. In order to be able to promote the identified potential, high investments in $\mathrm{CT}$ terminals and the network are required.

It became clear early on that certain freight train routes proposed under the Deutschlandtakt framework do not imply a true improvement, since the infrastructural framework conditions remain partially insufficient.

In summary, it can be concluded from the results to date that PFRP-based rail system transports with low access barriers improve the competitiveness, particularly for small- to medium-sized shipments. In effect, rail freight transport should urgently be more innovative, digital and flexible.

To substantially raise the rail freight market shares, transport policies need to promote the consistent expansion of a high-performance combined transport terminal network in order to multiply volumes, achieve faster transshipments and to enable flexible forms of operation.

It should be mentioned that there are single projects pointing in this direction that would lead to major improvements in the network if rolled out on a broad scale. With reference to corresponding press statements on this in October 2021, it was found that:

- the letter of intent for the construction of the Hamm multi-hub was signed [48], and

- a project for trial operations with automated freight trains was launched [49].

Thus, the practice is developing, albeit slowly, in the predefined sense of this approach.

KILIAN J. SAENGER, M.Sc. candidate ${ }^{1}$

E-mail: kilian.saenger@fh-erfurt.de

TIMO SIMON, M.Sc. ${ }^{2}$

E-mail: timo.simon@deutschebahn.com

FLORIAN HEINITZ, Prof. Dr. ${ }^{1}$

E-mail: heinitz@fh-erfurt.de

${ }^{1}$ Fachhochschule Erfurt

Altonaer Str. 25, 99085 Erfurt, Deutschland

2 DB Engineering \& Consulting $\mathrm{GmbH}$

Torgauer Str. 12-15, 10829 Berlin, Deutschland

\section{MACHBARKEITSUNTERSUCHUNG EINES \\ DEUTSCHLANDWEITEN VERTAKTETEN CONTAINERVERKEHRSSYSTEMS AUF DER SCHIENE}

\section{ABSTRAKT}

Ausgehend von einer Analyse der bisherigen Entwicklungen werden in diesem Beitrag bereits lange diskutierte Ansätze eines schnellen, vertakteten Netzes für den Kombinierten Verkehr auf der Schiene, dessen Leistungsfähigkeit am Zielwert des Modal Split ausgerichtet ist, aufgegriffen und konkretisiert. Hierfür wird ein vierstufiges Szenario für einen Markthochlauf entwickelt. Die vorgestellte Lösung beinhaltet potenziell neuartige Aspekte wie eine Netzgestaltung in Anlehnung an den integrierten Taktfahrplan von DeutschlandTakt Cargo, die Zugrundelegung der für 2030 prognostizierten Mengengerüste und eine Nachfragesegmentierung für einen streckenspezifischen Mix zweier Containertypen. Die aus dem Modell abgeleiteten Bewertungsindikatoren erlauben es, Erkenntnisse über die erreichbaren Kapazitäten und die Angebotsqualität der adressierbaren Güterverkehrsnachfrage sowie die daraus resultierenden Kosten-Nutzen-Verhältnisse zu gewinnen.

\section{SCHLÜSSELWÖRTER}

Schienengüterverkehr; Integraler Taktfahrplan; Kombinierter Verkehr; Güterverkehrsnachfrage; Trassenmanagement; Deutschland.

\section{REFERENCES}

[1] Allianz pro Schiene. [Market shares: The freight railways' road to success is slowing down]. Marktanteile - Der Erfolgskurs der Güterbahnen gerät ins Stocken; 2020. German. Available from: https://www.alli- 
anz-pro-schiene.de/themen/gueterverkehr/marktanteile/ [Accessed 30th June 2021].

[2] Eurostat. Freight transport statistics - modal split; 2021. Available from: https://ec.europa.eu/eurostat/statistics-explained/index.php?title=Freight_transport_statistics_-_modal_split [Accessed 30th June 2021].

[3] IRG-RAIL. Fifth Annual Market Monitoring Report; 2017. p. 44.

[4] Eurotransport. [First train departure at the Lehrte megahub]. Erste Zugabfahrt im Megahub Lehrte; 2020. German. Available from: https://www.eurotransport.de/ artikel/kombinierter-verkehr-in-neuen-dimensionen-erste-zugabfahrt-im-megahub-lehrte-11163178.html [Accessed 30th June 2021].

[5] Islam DMZ, Ricci S, Nelldal BL. How to make modal shift from road to rail possible in the European transport market, as aspired to in the EU Transport White Paper 2011. European Transport Research Review. 2016;8: 18. DOI: $10.1007 / \mathrm{s} 12544-016-0204-\mathrm{x}$

[6] Mittal T, Kuriakose PN. Intermodality - towards enhancing rail freight transportation prospects. In: Mitra S, Bandyopadhyay S, Roy S, Ponce Dentinho T. (eds.) Railway Transportation in South Asia. Contemporary South Asian Studies. Heidelberg: Springer; 2021.

[7] Gudelj A, Krčum M, Twrdy E. Models and methods for operations in port container terminals. Promet - Traffic\& Transportation. 2012;22(1): 43-1. DOI: 10.7307/ptt. v22i1.163

[8] Yan B, et al. Integrated planning of train schedule template and container transshipment operation in seaport railway terminals. Transportation Research Part E. 2020;142: 102061. DOI: 10.1016/j.tre.2020.102061

[9] Woodburn A. An analysis of rail freight operational efficiency and mode share in the British port-hinterland container market. Transportation Research D. 2017;51: 190-202. DOI: 10.1016/j.trd.2017.01.002

[10] Troche G. High-speed rail freight sub-report. In: Efficient train systems for freight transport. Stockholm: KTH Centre for Railway Technology; 2005.

[11] Abramović B, Zitricky V, Biškup V. Organisation of railway freight transport: Case study CIM/SMGS between Slovakia and Ukraine. European Transport Research Review. 2016;8(27). DOI: 10.1007/s12544-016-0215-7

[12] Smoliner M. System train paths as key to efficient infrastructure usage for on-track competition in ITF-regimes. Journal of Rail Transport Planning \& Management. 2019;12: 100147.

[13] Drábek M, Janoš V. Construction of differentiated periodic freight train paths in dense mixed traffic. Sustainability. 2021;13: 8330. DOI: 10.3390/su13158330

[14] Eurostat. Road Freight Transport Statistics. 2021. Available from: https://ec.europa.eu/eurostat/statistics-explained/index.php?title=Road_freight_transport_statistics

[15] DB Netz. [European Rail Freight Corridors]. Europäische Güterverkehrskorridore; 2020. German. Available from: https://fahrweg.dbnetze.com/fahrweg-de/ kunden/international/europ_korridore/europ_korridore allg-1393158. [Accessed 30th June 2021].

[16] Gašparík J, Abramovic B, Zitrický V. Research on dependences of railway infrastruc-ture capacity. Tehnički vjesnik. 2018;25(4): 1190-1195. DOI: 10.17559/TV-

\section{7}

[17] Spang K. [Project management of transport infrastructure projects]. Projektmanagement von Verkehrsinfrastrukturprojekten. Berlin: Springer; 2016. p. 355. German.

[18] Gleißner H, Femerling G. [Compact Edition: Transport, Elements - Management - Markets]. Kompakt Edition: Transport, Elemente - Management - Märkte. Wiesbaden: Gabler Verlag; 2016. p. 82. German.

[19] Janßen H. [Bottlenecks in logistics: problems, factors, effects]. Engpässe in der Logistik: Probleme, Faktoren, Auswirkungen. Thesis. Bremen University; 2015. p. 7-8. German.

[20] BMVI. [Target timetable Germany - $3^{\text {rd }}$ expert draft Freight traffic north/south]. Zielfahrplan Deutschland 3. Gutachterentwurf Güterverkehr Nord/Süd. 2020. German. Available from: https://assets.ctfassets. net/scbs508bajse/17 cfuH 7 tnFsRmdKXkCT3ah/5d0e96777d5cc45ff9341f1ef8d366e1/Netzgrafik_3._Entwurf_SGV_Nord.pdf [Accessed 30th June 2021].

[21] Fuchs K. [Non-discriminatory access to rail infrastructure in Germany]. Diskriminierungsfreier Zugang zur Eisenbahninfrastruktur in Deutschland. Wiesbaden: Gabler Verlag; 2014. p.73. German.

[22] DB Netz. [Rail Network Terms of Use of DB Netz AG 2020]. Schienennetz-Benutzungsbedingungen der $D B$ Netz $A G$ 2020. 2019. German. Available from: https://fahrweg.dbnetze.com/resource/blob/2872178/ 111912f79b2ed7e235e 74871a3ca5742/snb_2020-data. pdf [Accessed 30th June 2021].

[23] Clausen U, et al. [Integrated measures for a modal shift from road to combined and rail transport]. Integrierte Maßnahmen zur Verlagerung von Straßengüterverkehren auf den Kombinierten Verkehr und den Schienengüterverkehr. Fraunhofer Institut für Materialfluss und Logistik, Dortmund, 2019. German.

[24] Rochlitz KH. [Eight years of railway regulation the Federal Network Agency and competition on the railways]. Acht Jahre Eisenbahnregulierung. Die Bundesnetzagentur und der Wettbewerb auf der Schiene. 2014. p. 51. German.

[25] Fendrich L, Fengler W. [Railroad Infrastructure Manual]. Handbuch Eisenbahninfrastruktur. $3^{\text {rd }}$ ed. Berlin, Heidelberg: Springer Vieweg; 2019. p. 40. German.

[26] Islam D, Zunder T. Experiences of rail intermodal freight transport for low-density high value (LDHV) goods in Europe. European Transport Research Review. 2018;10: 24. DOI: $10.1186 / \mathrm{s} 12544-018-0295-7$

[27] [KV-Terminal in Bad Hersfeld] KV-Terminal in Bad Hersfeld?. Eisenbahn-Revue International. 2021;1(10). German.

[28] Koch J. [The Development of Combined Transport]. Die Entwicklung des Kombinierten Verkehrs. Wiesbaden: Dt. Universitätsverlag; 1997. p. 106. German.

[29] Moreno García-Loygorri J, et al. Communication Technologies for Vehicles; 2018. p. 82.

[30] Blom F, Harlander NA. [Logistics Management. The Development of Integrated Logistics Chains in Theory and Practice]. Logistik-Management. Der Aufbau ganzheitlicher Logistikketten in Theorie und Praxis. $2^{\text {nd }}$ ed. Renningen-M.: expert Verlag; 2003. p. 108. German.

[31] BMVI. [Operational limit parameters for freight trains]. Betriebstechnische Grenzparameter für Güterzüge; 2010. 
German. Available from: https://www.forschungsinformationssystem.de/servlet/is/324625/ [Accessed 30th June 2021].

[32] Oelfke, D. [Freight Forwarding and Logistics]. Speditionsbetriebslehre und Logistik. $20^{\text {th }}$ ed. Wiesbaden: Gabler Verlag; 2008. p. 93. German.

[33] Bundesrepublik Deutschland [One timetable for the whole country]. Ein Fahrplan für das ganze Land. 2020. Available from: https://www.bundesregierung.de/bregde/aktuelles/faq-deutschlandtakt-1826244. German [Accessed 30th June 2021]. German.

[34] BMVI. [Final report on the target timetable for Germany basic principles, conceptual design and economic evaluation]. 2021. German.

[35] Thiel HC, Menzel C. Smart Cargo Station; 2019. German. Available from: https://www-docs.b-tu.de/fg-eisenbahn/public/EI_1_2019_Menzel_Thiel.pdf [Accessed 30th June 2021].

[36] Innovatrain. [Lean handling technology] Schlanke Umschlagstechnik; 2021. German. Available from: http:// www.innovatrain.ch/de/containermover/

[37] Studiengesellschaft für den kombinierten Verkehr. Intermodal Map Worldwide Map for Infrastructure of combined traffic; 2021. Available from: https://www.intermodal-map.com [Accessed 30th June 2021].

[38] Kortschak B. CARGO NET. In: Nuzzolo A, Cappola P. (eds.) Limiti e Prospettive di Sviluppo des Transporto Ferroviario delle Merci, Proc. XII conbetno nationale e Seminario 2004 di Società Italiana dei Docenti di Transporti, Università degli Studi di Roma La Sapienzia, Milan; 2006. p. 185-203.

[39] Busche H, Weigand W. [Swiftly and interconnected across Germany and Europe. Deutschlandtakt Cargo An economic stimulus package towards a sustainable freight train system]. Güter zügig und vernetzt durch Deutschland und Europa. Deutschlandtakt Cargo - Konjunkturpaket für ein nachhaltiges Güterzugsystem; 2020. German.

[40] Winkler C, Mocanu T. Impact of political measures on passenger and freight transport demand in Germany. Transportation Research Part D: Transport and Environment. 2020;87: 102476. DOI: 10.1016/j.trd.2020.102476
[41] Greenbrier Europe. [Sggmrss 90' 6-axle articulated container transport car]; 2021. German. Available from: https://www.greenbrier-europe.com/de/produkte/product/sggmrss-90/. [Accessed 30th June 2021].

[42] VTG. [Container Wagon Sggns (s) 80 ‘ I41.080D]. 2021. German. Available from: https://www.vtg.de/waggonvermietung/unsere-flotte/i41080d/ [Accessed 30th June 2021].

[43] VTG. [Container Wagon Sggmrs(s) 90' | I71.090D]. 2021. German. Available from: https://www.vtg.de/waggonvermietung/unsere-flotte/i71090d/ [Accessed 30th June 2021].

[44] Winkler C, Kröger L, Nordenholz F, Lobig A. [Potential for modal shift to rail transport in Germany taking into account infrastructural issues and restrictions]; 2011. German. Available from: https://www.bmvi.de/SharedDocs/DE/Anlage/G/MKS/studie-verlagerungspotenzial-schienenverkehr-restriktionen.html [Accessed 30th June 2021].

[45] Commission of the European Communities. Handbook on the external costs of transport V1.1. DG VII; 2019.

[46] Commission of the European Communities. Sustainable and Smart Mobility Strategy - Putting European transport on track for the future. Commission Staff Working Documents 789, 2020.

[47] Müller S, Liedtke G, Lobig A. [Drivers and Barriers for Rail Freight Innovations]. Treiber und Barrieren für Innovationen im Schienengüterverkehr. Proceedings of the Conference Verkehrsökonomik und -politik. Berlin; 2016. German.

[48] Nordrhein-Westfalen. [More goods by rail: NRW State supports MULTI HUB WESTFALEN for climate-friendly rail logistics]. 2021. German. Available from: https:// www.land.nrw/de/pressemitteilung/mehr-gueter-auf-dieschiene-land-unterstuetzt-multi-hub-westfalen-fuer [Accessed 7th October 2021].

[49] Deutsche Bahn AG. [Testing of automated freight trains picks up speed]. 2021. German. Available from: https:// www.deutschebahn.com/de/presse/pressestart_zentrales uebersicht/Erprobung-automatisierter-Gueterzuege-nimmt-Fahrt-auf-6554858 [Accessed 7th October 2021]. 